\title{
Business, peacebuilding, violent conflict and sustainable development in Myanmar: presenting evidence from a new survey dataset
}

\author{
Jason Miklian and Ralf Barkemeyer
}

Jason Miklian is based at Centre for Development and the Environment, University of Oslo, Oslo, Norway. Ralf Barkemeyer is based at KEDGE Business School, Marseille, France.

Received 1 November 2020 Revised 15 February 2021 Accepted 5 April 2021

(C) Jason Miklian and Ralf Barkemeyer. Published by Emerald Publishing Limited. This article is published under the Creative Commons Attribution (CC BY 4.0) licence. Anyone may reproduce, distribute, translate and create derivative works of this article (for both commercial and non-commercial purposes), subject to full attribution to the original publication and authors. The full terms of this licence maybe seen at http://creativecommons.org/ licences/by/4.0/legalcode

\begin{abstract}
Purpose - This paper aims to present a new survey data set of 9,065 private sector respondents and other stakeholder groups, in Myanmar. The primary aim of this paper is to offer new insight avenues on local business-conflict-development interactions, and offer the full survey data set itself as an opensource research tool for scholars and practitioners.

Design/methodology/approach - The survey was conducted over smartphone in 2018. It asked questions that aimed to better understand the relationships between business, ethnic conflict, investment, corporate social responsibility and the United Nations sustainable development goals in Myanmar and in Rakhine State in particular.

Findings - The data set captures a series of significant differences in corporate leadership perspectives on the role of business in society, across sectors (e.g. banking, agriculture, retail, manufacturing, extractives) and variations across firm country of ownership (e.g. national firms, Global North firms, Indian firms, Chinese firms).

Research limitations/implications - The authors conclude with a brief discussion of possible research findings from the survey, offering suggestions for possible forward analysis. The authors offer here the raw survey data as an attachment for full global open-source use and application.

Practical implications - This data set offers a unique window into stakeholder perceptions and understandings of working through conflict, and the role of business in development in a fragile conflictaffected state (Myanmar). The authors also conduct two example analyses of the data set using ANOVA and Kruskal-Wallis tests to illustrate possible uses and findings of the data set.

Social implications - The authors briefly discuss social implications as well, particularly regarding the role of business in peacebuilding and development.

Originality/value - This data set offers a unique window into stakeholder perceptions and understandings of working through conflict, and the role of business in development in a fragile conflictaffected state (Myanmar). The authors also conduct two example analyses of the data set using ANOVA and KruskaL-Wallis tests to illustrate possible uses and findings of the data set.
\end{abstract}

Keywords Myanmar, United Nations sustainable development goals, Peacebuilding, Ethnic conflict, Private sector, Business ethics, Multinational corporations, Rakhine, Survey, Data set,

Corporate social responsibility (CSR)

Paper type Case study

\section{Rationale for survey and case background}

This survey data set on business, peacebuilding and development in Myanmar was commissioned in January and February 2018 to better understand the business and conflict environment in Myanmar after the outbreak of violence and military operations in Rakhine state. The role of business in peacebuilding and sustainable development has expanded 
rapidly over the previous decade, as business owners, shareholders and communities increasingly understand that they cannot extricate themselves from the societies within which they operate. The United Nations has supported this expansion, building and promoting a series of initiatives to help business be better social stewards, including the United Nations Global Compact and Business for Peace platforms.

Perhaps, the most heavily celebrated (and promoted) such expansion has been in Myanmar, which opened its economy in 2011-2012 to foreign investment after decades of restrictions. Most international organizations and businesses entered the country promoting a variation of liberal economic peace theory, that stronger economic ties with the rest of the world would make Myanmar more likely to democratize and less likely to backslide into conflict, a cornerstone philosophy of the Washington Consensus-supported platform of market expansion and regulation streamlining by the World Bank, Asian Development Bank and other international financial institutions (Findlay et al., 2015). Typically, market expansion is coupled with overhaul of financial regulations to increase efficiency, transparency and stability (Hendrix and Noland, 2015; Findlay et al., 2016). Some businesses embraced a more direct role as peacebuilders. As one example, the Myanmar head of Norwegian mobile telecoms firm Telenor, Petter Furberg, argued that his firm's work in creating mobile infrastructure and negotiating with rebel leaders was in fact nationbuilding (Furberg, 2016; Miklian, 2019).

However, economic liberalization can also be conflict-generating, particularly when economic growth exacerbates inter-group inequality (Sorens and Ruger, 2015; Midtgard et al., 2017). This is visible in Mynamar, where large influxes of foreign funding, coupled with a difficult transition from military rule to representative democracy, placed significant strains on Myanmar's social fabric. Shortly after opening, several of the country's longsimmering ethnic conflicts slid back into violent conflict, culminating most notably in a large-scale military operation in Rakhine state starting in 2014 that United Nations High Commissioner for Human Rights Zeid Ra'ad al-Hussein called "a textbook example of ethnic cleansing," killing or displacing over 700,000 citizens (United Nations, 2017; UNHRC, 2018).

In response, scholars have extensively studied and debated the role of economic opening upon society in Myanmar (Meyer and Thein, 2014; Jones, 2014; Ko, 2015; Crouch, 2017; Andrews et al., 2019), particularly in relationship to ethnic tensions after the period of opening (Mangan, 2018; Miklian, 2019). As if to punctuate the point, as of this writing (7 February 2021), a military junta has again taken over the country through a coup d'état. What is notable is that even though Myanmar's democracy prospects have significantly dimmed, there is little risk that the new liberalized economic system established over the previous decade is in similar danger. In fact, liberalization was a key trigger for the coup itself, enriching the junta enough to buy them widespread support and legitimacy for such action within the country's power corridors (Miklian and Katsos, 2021). In short, economic opening is here to stay in Myanmar, to great benefit to the country's military leaders.

However, there is less research into how economic opening has influenced the perceptions, livelihoods and actions of local stakeholders, in particular local small and medium-sized business owners. This group, constituting millions of people within the country, is often portrayed (incorrectly) as a passive actor as concerns the country's macroeconomic fortunes (Bissinger, 2020), but also has an active role in issues that strain social fabrics, and may have the ability to collectively either help promote ethnic conflict resolution (PressBarnathan, 2006; World Bank, 2017), or fan the flames of violence (Miklian, 2018). Mangan (2018) is a notable exception, particularly in the emphasis of business upon conflict and vice versa in Myanmar since 2012, but tends to focus on large, state-led or state-driven infrastructure types of business development, with less analysis of local business specifically. Another exception is a survey of 900 small and medium-sized enterprises in 
Yangon, with a business development focus (Kapteyn and Wah, 2016). Another valuable resource is the Asia Foundation's Myanmar Business Environment Index (Malesky et al., 2019), a survey of 4,800 businesses in Myanmar on issues of local economic governance. However, this survey focuses primarily on economic questions and excludes the primary sector (e.g. agriculture, forestry, mining), and also excludes foreign firms of all types.

The private sector is an integral part of society; just like any other set of actors, it is exposed to the consequences of violent conflict (Oetzel and Miklian, 2017) as well as any wider societal challenge faced in a given context (George et al., 2016; Miklian and Schouten, 2019). There are, however, also factors that set the private sector apart from other societal actors. Businesses control a significant amount of resources and capabilities that could potentially be used to address wider societal challenges (Porter and Kramer, 2019). To some degree, they also have the ability to self-organize in areas of weak governance (Börzel and Risse, 2010). The impact of their activities reaches far beyond the company gates, e.g. through the (over-) use of natural resources, tax payments, indirect employment or the utility of their products (Jenkins, 2005). Put simply, their decision-making can either help to address wider societal challenges, or amplify them.

In the context of Myanmar, like that of other states with histories of longstanding military leadership, the notion of "state" versus "military" versus "private sector" is significantly blurred, complicating distinct analysis (Woods, 2011). Military leaders have a long history in Myanmar of running the country's largest businesses and conglomerates, either themselves or through proxies like their families, and a large part of the country's 2011-2012 economic opening was predicated upon the military giving up political power but maintaining and expanding their economic grip, a process that began in 2008 (Ford et al., 2016). The most notable of these is post-coup leader, army general Min Aung Hlaing, who is also chair of the country's largest conglomerate (Union Myanmar Economic Holdings Limited), and whose son Aung Pyae Sone also runs a vast conglomerate incorporating telecoms, restaurants and prescription drugs services businesses, among others (Miklian and Katsos, 2021).

Scholars have taken several complementary approaches to attempt to understand and contextualize relationships between the military and business in Myanmar. McCarthy (2020) wraps this discussion under the term "military capitalism," a multi-decade endeavor to consolidate power and entrench military autonomy, supported by pro-democracy actors who calculated that shifting armed actors into commercial activities would sate their thirst for war and political power. Woods $(2011,2017)$ uses the term "ceasefire capitalism" to incorporate how the economic opening has been appropriated for elite financial gain through ceasefires in conflict zones, primarily by the military but also by some ethnic groups, under the guise of state-building. McCarthy and Farrelly (2020) expand this concept as concerns elite rent-seeking and the liberal peace project, arguing that the illiberal peace generated in such areas constitutes a "peri-conflict peace" that maintains economic growth and access. Einzenberger (2018) takes a similar tack in his notion of "frontier capitalism," the selling of modernization megaprojects in Myanmar's periphery as essential to the country's economic development as a means to accelerate dispossession of challengers to the state, again with the military playing the key role in both the ground clearing as well as the profit taking. Last, conflict minerals and illicit substances have formed a large historical and contemporary portion of military finances, including but not limited to jade and opium (Kramer, 2012; Talbott et al., 2012).

All four distinct strands share a common thread: the notion of "capitalism" in Myanmar is more often used by the military as an explicit tool for political and territorial control than as an implicit economic framework or aspiration for society. This is not a surprising development. Many scholars (Taylor, 2013) clearly articulated how economic expansion would likely be used by the military in the spirit of consolidation against, not diffusion toward, democracy. This "recalibration" by the military into a series of business entities was not accidental (Aung-Thwin, 2013), but a purposeful reimagining of itself, using democracy 
as a transitive, not permanent state for the country. Moreover, the role of powerful business in society has traditionally been one of negotiation with a weak state over goods provision, be it through philanthropy or social goods provisions in exchange for tax tradeoffs (McCarthy, 2020), leading many big business areas (particularly extractives) to resemble the historical "company towns" where the business, not government, is the primary service provider. Under these contexts, the very concept of what a large business is and means to the country is much more complex in Myanmar than what the private sector typically represents elsewhere.

At heart, economic liberalization policies alone struggle to cohesively address socioeconomic grievances (Ahearne, 2009), particularly when those in charge of implementing inclusive policies are the same individuals and groups who may have the most to comparatively lose from such arrangements. In Myanmar, these cleavages are sharp, grounded in discussions of sovereignty (Grundy-Warr and Dean, 2016), and exacerbated by the fact that many of the country's richest resource regions are populated by historically disadvantaged ethnic groups (Simpson, 2014). The result has been a liberalization that exacerbated inequality toward elites, particularly military conglomerates, entrenching their political and economic power despite their lack of formal roles until 2021 (Bunte, 2016; Ford et al., 2016; Jones, 2014).

Other evidence (Hedstrom and Olivius, 2020) suggests that the disadvantaged and disenfranchised, particularly along ethnic and gender lines, are worse off than before liberalization. Again, cleavages are strongest in Myanmar's peripheries, where conflict-ceasefire cycles can entrench military-business links at the expense of local groups promised more autonomous "free market" dynamics that do not materialize in practice (Jones, 2016). Many of these processes predate the economic opening itself, with decades of foreign (Chinese) investment enriching the junta at the expense of promised development, particularly with extractive projects in the periphery (Kudo, 2006), often rewarding military conglomerates in particular (Min and Kudo, 2016). With the exact role of liberalization in these processes, a matter of intense academic debate (Rogers, 2012; Green, 2013), we see a deep need to add empirical assessments of Myanmar citizens themselves to better understand these processes and cleavages, particularly in reference to the gap that exists between knowledge of elite businesses (as most of the above sources study), and small- and medium-sized firms, which constitute a much larger proportion of the country's workers and firms.

\subsection{Survey rationale and question formulations}

Therefore, we argue that knowledge of these stakeholders' motivations; relationships between economic growth and violence; perceptions of the causes and consequences of local violence; relationships between business and society in times of crisis or fragility; and variations between subsets of these actors may shed significant light on which precise economic mechanisms are most likely to be conflict reducing or conflict generating. This survey aimed to help fill these knowledge gaps. Even though much progress has been made in terms of understanding business responses to grand challenges such as combating climate change, eradicating poverty or tackling corruption (Kolk et al., 2017), the business-conflict and business-peace relationships remain poorly understood. In addition, research into the role of business and society has tended to emphasize large multinational companies as well as companies hailing from the Global North (GN) (Pisani et al., 2017). The extant data set therefore has the potential to make a threefold contribution to this literature, by shedding light on how smaller firms based in the Global South (GS) are operating in fragile environments.

Our survey questions (see Appendix) were designed to help decipher how the private sector in Myanmar sees itself and its actions within the peace and conflict landscape, what potential role it can and does play in peacebuilding, its actions for peace through the United 
Nations sustainable development goals (SDGs) and the impact of the private sector more broadly on economic development and liberal economic peace in Myanmar after the 2012 opening. In particular, the survey questions were designed to tease out possible sectoral and foreign/domestic differences in how firms see their peace and sustainable development roles, the importance of the CEO/owner in such decision-making and a more overall comprehension of how firms see themselves within complex conflict settings. We see this survey, and the questions asked therein, as complementary to the Myanmar Business Environment Index, building upon their study of economic governance to also explore more direct social roles that businesses may play, and the perceived impacts of such.

Questions were developed to help build evidence to support or challenge the following five assumptions commonly seen in the literature, as articulated below. We note that these assumptions are drawn from a review of key texts in the business and peacebuilding literature, in particular those texts that attempt to categorize business efforts for peace (Oetzel et al., 2009; Oetzel and Getz, 2012; Miklian, 2018), those works that attempt to understand the conditions and environments within which such activities have deepest impact on societies (Trompenaars, 1996; Franks et al., 2014; Forrer and Katsos, 2015) and studies of business and social investment strategies in conflict zones (Mills and Fan, 2006; Nielsen and Riddle, 2009; Pirson and Lawrence, 2010; Driffield et al., 2013).

With these texts in mind, we set out to interrogate assumptions on business and peace in Myanmar, following Forrer and Katsos' (2015) characterization of such locations and dynamics as residing in the "buffer condition" where peace-positive action by business can have particular relevance. Assumptions follow:

A1. The private sector sees itself as a positive player in peacebuilding, but foreign firms are more interested than their domestic counterparts to participate in peacebuilding.

Previous findings from two multi-year business-peace research projects (Miklian et al., 2018; Ganson et al., 2019) confirmed that private sector actors can indeed play peacepositive roles. Further, business interest in peacebuilding has increased significantly, with peace projects undertaken by the private sector tripling in the past five years under some indicators (Melin, 2020). However, most existing literature focuses on foreign multinational corporations. Foreign firms can be quite vocal about the peace-positive roles that they play, but does this mean that they are more interested and active participants, or do they simply have larger platforms to promote such activities? Local/national firms in Myanmar show interest in some elements of peacebuilding, such as business and human rights frameworks, but logistical challenges including a lack of local language resources (Bowman and Guest, 2019) could mask the true scale of local business interest in peacebuilding. In particular, emerging evidence suggests that business philanthropy in Myanmar appears to play an outsize role in corporate social responsibility compared to other social engagement mechanisms (Dove, 2017; Tan and Lam, 2017). We aimed to learn more about what national-level firms, and particularly smaller firms, felt regarding their desired role in peacebuilding processes.

A2. Peace interests align with business interests, but there are sectoral differences based upon particular peace trajectories and prioritizations.

In Myanmar, businesses, particularly foreign firms, have a long history of partnering with rights-abusing actors in exchange for country access (Holliday, 2005), and business-conflict relationships are both robust and long-lasting, particularly when issues such as corruption and cronyism are considered as a type of structural violence upon society. But at the same time, business-supporting international institutions and governments, including the World Bank and the Myanmar government, argue that business and increased investment is a peace-positive activity (World Bank, 2020). However, we know less about how peace interests align with business interests at the local level, or if they 
are even perceived as mutually beneficial initiatives at all. Emerging evidence (Joseph et al., 2020) suggests that sectoral differences exist, and are significant as concerns peace impact. We aimed to understand if these perceptions of access being more important than human rights are changing, and if so, in which ways they are changing and who may be leading this change. Further, we aimed to learn if such perceptions varied across sector, including in retail, manufacturing, agriculture, extractives and similar:

A3. CEOs are the most optimistic about business impact on peace and development as compared to others in the organization.

Building on previous research suggesting that the CEO plays a key role in business-peace trajectories (Oetzel and Miklian, 2017; Rettberg and Miklian, 2019), we sought to better unpack not only what business leaders do for peace (or not), but how their perceptions of the peace and conflict landscape influence their decision-making. Further, we sought to explore if business leaders from different backgrounds (e.g. Global North vs Global South, Chinese vs Burmese vs Indian) had significant variations in how they approached issues of peacebuilding and their roles in building sustainable societies. This is of particular interest given the power of large business conglomerates upon society in Myanmar more generally (Min and Kudo, 2014):

A4. Firms see conflict as a significant barrier to investment.

Firms are typically assumed to be interested in a stable operating environment (Margolis and Walsh, 2003). Uncertain and volatile governance contexts, changing institutional environments and the probability of discontinuous change (Winn et al., 2011) can be especially problematic in sectors with very long investment horizons, such as mining or oil and gas installations. Furthermore, civil society activism can, under certain conditions, act as a powerful deterrent for investment in conflict zones (Westermann-Behaylo, 2009). Large companies with highly visible brand names in particular have been found to be exposed to public pressure in this context (Hendry, 2006; Rehbein et al., 2004).

We also sought to explore if firms within a conflict zone (in this case Rakhine state) perceived investment-peace links differently to those outside the conflict but still in-country. Further, we sought to explore if Myanmar, Chinese and Indian business stakeholders expressed different perceptions or values on such issues, building upon work by Rao (2019), Mitra and Gaur (2020), and others:

A5. There are sectoral differences in the private sector's understanding of the importance of the investment/democracy and investment/peace relationships.

To a certain degree, the characteristics of a given sector are likely to shape its exposure to peace and conflict. A company's degree of vertical integration, the complexity of supply chains, the nature of its workforce, the dependency on highly trained labor or the nature of transport and logistics networks can all be expected to differ from sector to sector, and thus to result in sector-specific manifestations of the business-conflict-development nexus.

From these five assumptions, and drawing upon the frameworks and knowledge gaps as developed particularly by Oetzel et al. (2009) as well as Oetzel and Getz (2012), we developed our survey questions (see Appendix). We also note that a complementary component of our analysis, focusing on corporate social responsibility (CSR), was published in 2019 (Barkemeyer and Miklian, 2019).

\section{Survey methodology}

We surveyed 9,065 corporate practitioners and other stakeholders (such as NGO representatives, government officials, auto-entrepreneurs) in Myanmar in both Burmese and English in 2018. We recognized the inherent challenges in translation for the questionnaire, in particular for potentially sensitive topics, so aimed to develop all translations in a way that 
captures original meaning of the English question as opposed to a word-for-word translation (Kleiner et al., 2009).

The survey was conducted by RIWI, and geo-coded to the city level of analysis. Regarding specific methodological structure, we adapt from Vatillum's (2019, n.p.) five-step framework on RIWI methodology: respondents are gathered when a random internet user enters a dormant or lapsed URL and lands on a randomized RIWI survey site in the target region; RIWI autorecognizes and removes bots, avoids ad blocks and filters out trademarked websites in targeted geographies; RIWI autorecognizes device type and OS of the target audiences of interest in all information environments, across any device; RIWI autovalidates location and delivers video message or survey for continuous target audience analysis; and correlations of significance are autodetected to enable time series, predictive trends or custom analytics.

Further, per Vatillum (2019, n.p. abridged),

[...] the RIWI engine is dependent on Web users making typographical errors when inputting an address into their URL bar. Once a typographical error is made users are redirected to a digital survey. By randomly intercepting online survey respondents and generating privacy-compliant survey data from random respondents, RIWI provides survey information that is free of many biases of traditional online survey techniques, notably online coverage bias, and coverage bias generally. It is a statistically peer-reviewed means of continuously reaching the widest possible, non-incentivized, and random sample of global respondents.

The following additional survey methodology information is adapted from Barkemeyer and Miklian (2019, pp. 7-8), selected as a relevant text for our discussion; here as it uses the same survey instrument (albeit a different portion of the same open-source data set) in its analysis:

A survey instrument was deemed as particularly appropriate given the industry structure in Myanmar, with a dominance of small and medium-sized firms that tend not to maintain more formalized communication channels such as corporate annual reports or corporate websites. RIWI applied a Random Domain Intercept Technology (RIWI, 2020) to minimize sampling bias and aim at a representative sample of the population of corporate practitioners in the Myanmar context. This research technique is a well-established big data approach that has been applied in a variety of different contexts, ranging from surveys on mental health stigma (Seeman, 2015) to opinion-mining of citizen-driven accountability (Lee, 2014).

While selection bias of a sample weighted towards the more affluent and/or technologically engaged would normally be of concern (Myanmar has less than $50 \%$ smartphone penetration, but this statistic is growing rapidly), for the purposes of our study we assumed that any business practitioner with the capability to have societal impact would have such access. This format thus carried a positive selection benefit for the individuals that we wished to reach. We asked 15 closed questions related to our above hypotheses, with three possible additional questions based upon responses. Due to the limitations of the survey format, we restricted our questions to 8 of the 17 SDGs: Goals 1, 4, 5, 8, 9, 12, 13, and 16, also providing an "other" option. We selected these eight based on previous pilot research suggesting these as the most important for firms working in Myanmar (Miklian, 2017a, 2017b; Miklian, 2019).

See Appendix for full survey questions, in addition to standardized questions on age/ gender and language preference. Full data set and supporting documentation is available for open use and download at the Harvard Dataverse: dataverse.harvard.edu/dataset. xhtml?persistentld=doipercent3A10.7910percent2FDVNpercent2F8NVOYQ. We note that because of RIWI limitations, full Likert scale question formats were not used and thus only indirect comparisons with similar surveys (Oetzel and Getz, 2012) were possible.

\section{Preliminary findings for exploration and implications}

We stress first and foremost that the analysis contained below is strictly of a preliminary nature. More sophisticated empirical assessment will likely lead to more significant and 
more fine-grained results. That said, we offer here a basic discussion of four emergent correlations. We take care to note that these correlations have varying degrees of robustness and exact percentages do vary based upon the variables selected for inclusion/ exclusion. We, therefore, recommend scholars to explore the rich data more deeply, particularly through regression analysis or other tools rather than considering these simple observations as the most significant survey findings per se.

In support, we attach two Excel documents presenting analysis with both ANOVA and Kruskal-Wallis tests, one disaggregating between domestic and international and the other using the entire sample, to illustrate one such way of data analysis for reference. Note that sample sizes vary significantly across questions, ranging from around 2,500 responses from a wide range of stakeholders (including around 700 private sector respondents) to more general questions related to the Myanmar context, down to around 120 responses (55 private sector) in relation to questions that specifically focused on the Rakhine conflict. In particular, questions that specifically focus on the Rakhine conflict as well as the perspectives of senior management need to be treated with caution because of the relatively low number of responses. Readers may reference the complete data set linked to this paper for $n$ numbers for each individual question. Nevertheless, a number of pertinent trends and patterns emerge from the data set.

First, the data suggests that gaps between Myanmar, Asian and GN firms on business, development and peacebuilding connections are significant. It can be seen that Myanmar nationals as well as other Southeast Asian respondents have significantly more positive views on the role of the business community in peacebuilding than respondents of other nationalities. At the same time, a significantly more positive view is also taken by employees of foreign-owned firms when compared to domestic businesses as well as other stakeholders. Perhaps unsurprisingly, foreign firms also have more positive views on the impact of foreign investment on social development in Myanmar. Regarding sector-level differences, respondents from oil and gas firms consistently take more positive positions on the role of business in peacebuilding, encouraging democracy and promoting social development. At the other end of the spectrum, agriculture as well as technology and telecommunications consistently voice more negative views when compared to other sectors. Even though CEOs represent only a relatively small fraction of responses (typically between 30 and 60 responses), one notable pattern that emerges is that senior management consistently tends to take more pessimistic positions in relation to the role of business in peacebuilding and promoting democracy, whereas respondents in middlemanagement positions voice more positive views.

In general, GN firms appear much more optimistic about the business community's ability to contribute to peace in Myanmar (60\%, versus closer to 30\% for Burmese, Indian and Chinese). However, they were also the most likely to say that business is not relevant to peacebuilding at all (40\%, as opposed to $10 \%-20 \%$ of others). Most respondents were supportive of the role of foreign investment on social development (about $75 \%$ agreed), with Burmese respondents the most optimistic (85\%) and Chinese respondents the most skeptical (50\%).

Second, respondents generally agreed that the Rakhine conflict slightly decreased the amount of foreign investment in the country and made business slightly more difficult to conduct, with Burmese respondents generally the most pessimistic. However, those operating in Rakhine itself were more optimistic. A total of $35 \%$ felt that the conflict significantly increased investment and profitability. Also, the desired role by business in peacebuilding was strong for national firms and across sectors. Over $80 \%$ of respondents in all sectors save banking (50\%) felt that business was relevant to peacebuilding in Myanmar. Of those who thought it relevant, about 2/3 of respondents in each sector save extractives thought that business should do even more for peace than it does. Extractives were the opposite; 2/3 thought that their firms should do less. Chinese firms were the most 
skeptical of the business contribution to peace as a whole (60\% said business did not contribute or business was not relevant, second highest (GN) was $44 \%$ ).

Third, there were significant variations across sectors. For example, agricultural firms were much less interested in business efforts in peacebuilding than other sectors, by a factor of four - but were the most active in CSR of all sectors. Those in the banking sector were more likely to say that their profits increased because of Rakhine than other sectors - yet nearly $20 \%$ of banking firms also claimed to contribute to Goal 16: Peace Justice and Strong Institutions - the highest sector by far. Both banking and extractives were more likely to say that the Rakhine conflict made their businesses more profitable, perhaps because of increased remittances for banks and increased access for extractives.

Returning to the five propositions mentioned earlier, we discuss each in turn:

$P 1$. The private sector sees itself as a positive player in peacebuilding, but foreign firms are more interested than their domestic counterparts to participate in peacebuilding.

Our findings did not provide support for this assertion. Foreign firm respondents were in fact the most pessimistic about peacebuilding participation, with most expressing support for a "business as usual" approach wherever possible. This is a surprising finding, given the importance that most foreign firms place on their activities in Myanmar being peace-positive and constituting a positive impact for society and securing the transition from the military junta to democracy. While a precise reason remains unclear, it may reflect the fact that for many foreign firms, conflict and peace concerns represent a political risk and security issue. But for national - and especially local - firms, it is an existential issue. A foreign firm can move; a local firm typically cannot. It may also reflect upon the performative nature of many business efforts for peace - most firms prefer high-profile ceremonial commitments to peace that do not carry the risks (and unclear rewards) of more in-depth engagement in peacebuilding activities that may fail despite their best efforts:

P2. Peace interests align with business interests, but there are sectoral differences based upon particular peace trajectories and prioritizations.

Our findings provided strong support for the sectoral differences component, and sector variations in business and conflict appear to carry significance. For example, respondents from the banking sector did not see themselves as peace-relevant as others, agricultural firm respondents were less interested in peace, yet retail and manufacturing respondents were the most supportive of business engagement in democracy, possibly opening a question if some business sectors are more naturally "friendly to democracy" than others. The findings provided less support for the alignment between peace and business interests, perhaps because of the difficulty for a closed response survey to tackle such a multi-faceted relationship, and possible variations between sectors on the very definition of "peace" and what "peacebuilding" by business means operationally:

P3. CEOs are the most optimistic about business impact on peace and development as compared to others in the organization.

Despite persuasive arguments about the role and importance of CEO in peace, including by the authors (Fort, 2015; Rettberg and Miklian, 2019), CEOs surveyed were much more skeptical of business in peacebuilding than management or entry-level staff. A total of $42 \%$ of CEOs said peacebuilding activities were not relevant to business, as opposed to only $19 \%$ of management, with most managers considering peacebuilding highly relevant and firms should do more. CEOs were also much more likely to respond that the Rakhine conflict has had a negative impact on profit, and that helping ethnic minorities hurts profits. For the latter, there is a gradual increase from CEO to management to mid-level to entry level, with entry level the most optimistic about inclusion of minorities for profitability. CEOs were more negative on if foreign investment is good for social development. A total of $60 \%$ say it makes social development much worse as opposed to $10 \%$ of all other levels. There was a similar 
correlation on the question if the business community contributes to peace ( $35 \%$ say no and it should not, compared to $8 \%$ for all others). These findings may be an outlier because of low sample size, or a function of variations in understanding the environment and the relationship to impact on short-term profits, or could be Myanmar-specific pessimism, which is currently unclear:

P4. Firms see conflict as a significant barrier to investment.

Across the sample, responses are varied, with a certain share of respondents even stating that the conflict in Rakhine state has increased investment in Myanmar. However, the majority view appears to be that it has in fact led to a decrease in investment. The need for a stable operating environment (Margolis and Walsh, 2003) and international civil society pressure (Westermann-Behaylo, 2009) may both have contributed to this view, in particular among export-oriented firms:

P5. There are sectoral differences in the private sector's understanding of the importance of the investment/democracy and investment/peace relationships.

At the same time, distinct sector-level patterns emerge within the sample. Manufacturing, retail and agriculture appear to suffer most from decreasing investment levels in a fragile environment. Perhaps counterintuitively, extractive industries, despite their typically long time horizons, are associated with more positive views on the issue. Likewise, respondents from the banking sector appear to be somewhat more positive. Both the variation in responses within sectors and the differences between sectors make explorations into the sector-level manifestations of the business-conflict-development nexus a promising avenue for future research.

\subsection{Research and societal implications}

This data set is designed to be a resource for scholars to analyze either in a standalone format or in conjunction with other databases/surveys/sources. Full data set and supporting documentation is available at the Harvard Dataverse: dataverse.harvard.edu/dataset.xhtml? persistentld=doipercent3A10.7910percent2FDVNpercent2F8NVOYQ. Regarding possible uses of data, we see at least three research possibilities.

First, this data may offer context and conditionality to the "business as conflict profiteer/ peace profiteer" literature. This literature comes down on all sides of the spectrum if firms are "good guys" or "bad guys" in conflict, with prolific examples. But, what most of the literature assumes is that conflict - unless you are dealing in a sector like weapons - is bad for business, which is in turn bad for society (e.g. economic liberal peace). However, the conflict-profitability connection is complex and conditional, conflict ecosystems can exist symbiotically with business, and conflict can have a variety of positive and negative impacts even for the same firm at the same time in different regions of the country. This data set can help offer context to research questions that attempt to provide nuance on the role and impact of business in Myanmar and possibly other conflict societies.

Second, the data set provides clear evidence of significant variation across sectors on business and peace issues. However, more research is needed to decipher the meaning behind these variations, their importance and their impact upon business and conflict dynamics. In addition, it is unclear to what extent these variations are Myanmar-specific in nature, and which may reflect broader sectoral differences. The preliminary findings encourage additional advanced analysis through peacebuilding scholarship in particular, as most peacebuilding research has little comparative evidence across sectors in business-peace interactions, aside from the extensive case work on extractives on conflict zones and analyses of agriculture through land reform/grabbing and conflict, with most examinations of one big firm that has major societal influence. This data set can help inform 
research questions on the importance of sector variation on the role of business in peacebuilding.

Third, this data may help build theory on the role of business in peacebuilding. Much existing literature (for a synopsis, see, e.g. Miklian, 2018) finds that firms are not very interested in engaging in peacebuilding, but the data here suggests that this relationship is more nuanced. This disconnect may be squared by deeper analysis at the lower uptake by upper management - those very people who are typically the ones interviewed at firms on business-peace issues. However, literature on the role of the CEO as the primary catalyst for peace seems to hold, particularly in Rakhine. In support, these findings can help add nuance to other elements of bussiness and pease dicussions. These include a possible greater polarization amongst foreign firms, and divergent understandings of bussiness impact upon confict between foreign and domestic firms. This may challenge theories assuming that foreign firms are more responsible (or at least more accountable) peace actors than GS firms, and that GN firms have one similar set of (more extensive) rules on peace and development engagement, and GS firms have another, less sophisticated set. Thus, this data can help inform research questions on the importance of headquarters locations and management styles and structures on activities that businesses take in fragile and conflict-affected states, and possibly their relative importance.

For all three of the above streams, we stress that these sorts of "thin quantitative" studies drawn from public survey data are designed first and foremost to be theory building in nature, to open up initial empirical evidence for how societies understand powerful actors in their social environments. This is the primary purpose of this article, which is to make the full data set available for full, free, open-source use. An essential next step is to better understand why respondents responded in the way that they did, particularly where conventional narratives or theories may assume or predict alternative results. Here, we propose and promote qualitative or ethnographic analysis that has the ability to more deeply decipher rationales, relationships and motivations behind respondent selections, and better contextualize such beliefs to their broader socio-political and socio-economic contexts in Myanmar. Our previous qualitative research on this manner in other contexts (Miklian and Rettberg, 2019; Miklian et al., 2019; Miklian, 2020; Miklian and Medina-Bickel, 2020) supports this approach, and serves as just one of many possible guideposts for further exploration by qualitative scholars.

Regarding potential societal implications of this data set, we see several possible discussion and impact windows. Most clearly, a more sophisticated understanding of how the private sector impacts upon peace and conflict processes is an essential matter for development. As most scholars (and many policymakers) increasingly recognize, conflict-business relationships are much more complex than seeing firms simply negatively as "war profiteers" or simply positively as "doing well by doing good." For peacebuilding practitioners, unpacking the varied and at times contradictory motivations, perceptions and activities of businesses - both large and small, foreign and domestic - helps fold these essential actors into durable peace processes. For businesses, knowing better how their peers see the role of business in society - and knowing where they can promote positive peace impacts while avoiding harm - can deliver societal good and improve the bottom line. These findings can also help us question assumed differences between GN and GS actors and business cultures, perhaps including assumptions about within-Asia variation on business roles in fragile societies.

\section{References}

Ahearne, J. (2009), "Neoliberal economic policies and post-conflict peacebuilding: a help or hindrance to durable peace?", POLIS, Vol. 2, pp. 1-16.

Andrews, T., Nimanandh, K., Htun, K.T. and Kantabutra, S. (2019), "Responsible cronyism in transition: understanding changing attitudes to business corruption in Myanmar", Asia Pacific Business Review, Vol. 25 No. 4, pp. 554-570. 
Aung-Thwin, M. (2013), "Myanmar in 2013: integration and the challenge of reform", Southeast Asian Affairs, Vol. 2014 No. 1, pp. 203-223.

Barkemeyer, R. and Miklian, J. (2019), "Responsible business in fragile contexts: comparing perceptions from domestic and foreign firms in Myanmar", Sustainability, Vol. 11 No. 3, p. 598.

Bissinger, J. (2020), Good Practice in Subnational Economic Governance in Myanmar: Findings from the 2019 Myanmar Business Environment Index, The Asia Foundation, Yangon, Myanmar.

Börzel, T.A. and Risse, T. (2010), "Governance without a state: can it work?", Regulation \& Governance, Vol. 4 No. 2, pp. 113-134.

Bowman, V. and Guest, D. (2019), "Business and human rights education in Myanmar: the first five years of Myanmar Centre for responsible business", in Osaka, H. (Ed.), Human Rights Education in AsiaPacific: Volume Nine, Asia-Pacific Human Rights Information Center, Osaka.

Bunte, M. (2016), "Myanmar's protracted transition: arenas, actors, outcomes", Asian Survey, Vol. 56 No. 2, pp. 369-391.

Crouch, M. (Ed.) (2017), The Business of Transition: Law Reform, Development and Economics in Myanmar, Cambridge University Press, Cambridge.

Dove, C. (2017), "Giving trends in Myanmar: more than merit making", Austrian Journal of South-East Asian Studies, Vol. 10 No. 2, pp. 2-17.

Driffield, N., Jones, C. and Crotty, J. (2013), "International business research and risky investments, an analysis of FDI in conflict zones”, International Business Review, Vol. 22 No. 1, pp. 140-155.

Einzenberger, R. (2018), "Frontier capitalism and politics of dispossession in Myanmar: the case of the Mwetaung (Gullu Mual) nickel mine in Chin state", Austrian Journal of South-East Asian Studies, Vol. 11 No. 1, pp. 13-34.

Findlay, R., Park, C. and Verbiest, J.P. (2015), "Myanmar: unlocking the potential", Asian Development Bank Economics Working Paper \#437.

Findlay, R., Park, C. and Verbiest, J.P. (2016), "Myanmar: building economic foundations", Asian-Pacific Economic Literature, Vol. 30 No. 1, pp. 42-64.

Ford, M., Gillan, M. and Thein, H.H. (2016), "From cronyism to oligarchy? Privatisation and business elites in Myanmar", Journal of Contemporary Asia, Vol. 46 No. 1, pp. 18-41.

Forrer, J.J. and Katsos, J.E. (2015), "Business and peace in the buffer condition", Academy of Management Perspectives, Vol. 29 No. 4, pp. 438-450.

Fort, T. (2015), The Diplomat in the Corner Office, Stanford University Press, Stanford, CA.

Franks, D., Davis, R., Bebbington, A., Ali, S., Kemp, D. and Scurrah, M. (2014), "Conflict translates environmental and social risk into business costs", Proceedings of the National Academy of Sciences, Vol. 111 No. 21, pp. 7576-7581.

Furberg, P. (2016), Keynote presentation. Oslo Business for Peace Foundation event. 7 May.

Ganson, B., Miller, B., Cechvala, S. and Miklian, J. (2019), "Capacities and Limitations of Private Sector Peacebuilding", CDA Collaborative Learning Projects, Cambridge, MA.

George, G., Howard-Grenville, J., Joshi, A. and Tihanyi, L. (2016), "Understanding and tackling societal grand challenges through management research", Academy of Management Journal, Vol. 59 No. 6, pp. 1880-1895.

Green, P. (2013), “Islamophobia: Burma's racist Fault-Line”, Race \& Class, Vol. 55 No. 2, pp. 93-98.

Grundy-Warr, C. and Dean, K. (2011), "Not peace, not war: The Myriad Spaces of Sovereighnty, Peace and Conflict in Myanmar/Burma", in Flint and Kirsch (Eds), Reconstructing Conflict: Intergrating War and Post-War Geographies, Ashgate, London.

Hedstrom, J. and Olivius, E. (2020), "Insecurity, dispossession, depletion: women's experiences of post-war development in Myanmar", The European Journal of Development Research, Vol. 32 No. 2, pp. 379-403.

Hendrix, C. and Noland, M. (2015), "Myanmar: cross-cutting governance challenges", Innovation and Economic Growth Series \#5, East-West Center, Washington, DC.

Hendry, J.R. (2006), "Taking aim at business: what factors lead environmental non-governmental organizations to target particular firms?”, Business \& Society, Vol. 45 No. 1, pp. 47-86. 
Holliday, I. (2005), "Doing business with rights violating regimes corporate social responsibility and Myanmar's military junta", Journal of Business Ethics, Vol. 61 No. 4, pp. 329-342.

Jenkins, R. (2005), "Globalization, corporate social responsibility and poverty", International Affairs, Vol. 81 No. 3, pp. 525-540.

Jones, L. (2014), "The political economy of Myanmar's transition", Journal of Contemporary Asia, Vol. 44 No. 1, pp. 144-170.

Jones, L. (2016), "Understanding Myanmar's ceasefires: geopolitics, political economy and statebuilding", in Sadan, M. (Ed.), War and Peace in the Borderlands of Myanmar, NIAS Press, Copenhagen.

Joseph, J., Katsos, J. and Daher, M. (2020), "Local business, local peace? Intergroup and economic dynamics", Journal of Business Ethics, Online First.

Kapteyn, A. and Wah, S.H. (2016), "Challenges to small and medium-size business in Myanmar: what are they and how do we know?", Journal of Asian Economics, Vol. 47 No. 4, pp. 1-22.

Kleiner, B., Pan, Y. and Bouic, J. (2009), "The impact of Instructions on survey translation: an experimental study", Survey Research Methods, Vol. 3 No. 3, pp. 113-122.

Ko, S.Z. (2015), "Myanmar's experience in regional integration: Implications for trade, FDI, and sustainable development", in Djajadikerta, H.G. and Zhang, Z. (Eds), A New Paradigm for International Business, Springer, London, pp. 325-341.

Kolk, A., Kourula, A. and Pisani, N. (2017), "Multinational enterprises and the sustainable development goals: what do we know and how to proceed?", Transnational Corporations, Vol. 24 No. 3, pp. 9-32.

Kramer, T. (2012), "Ending 50 years of military rule? Prospects for peace, democracy and development in Burma", Norwegian Peacebuilding Centre, Oslo.

Kudo, T. (2006), "Myanmar's economic relations with China: can China support the Myanmar economy?", IDE Discussion Paper. No. 66.7.

Lee, S.S. (2014), Open Financial Data: Demand, Capacity and Citizen Engagement in Online and Offline Communities, World Bank, Washington, DC

McCarthy, G. (2020), Military Capitalism in Myanmar, ISEAS-Yusof Ishak Institute, Cambridge (UK).

McCarthy, G. and Farrelly, N. (2020), "Peri-conflict peace: brokerage, development and illiberal ceasefires in Myanmar's borderlands", Conflict, Security and Development, Vol. 20 No. 1, pp. 141-163.

Malesky, E., Dulay, D. and Keesecker, J. (2019), The Myanmar Business Environment Index: Measuring Economic Governance for Private Sector Development, DaNa Facility and The Asia Foundation, Yangon.

Mangan, C. (2018), "Private Enterprises in Fragile Situations: Myanmar", International Growth Centre (IGC) country report. IGC, London.

Margolis, J.D. and Walsh, J.P. (2003), "Misery loves companies: rethinking social initiatives by business", Administrative Science Quarterly, Vol. 48 No. 2, pp. 268-305.

Melin, M. (2020), "The business of peace: understanding corporate contributions to conflict management", International Interactions, Vol. 47 No. 1, pp. 107-134.

Meyer, K. and Thein, H.H. (2014), "Business under adverse home country institutions: the case of international sanctions against Myanmar", Journal of World Business, Vol. 49 No. 1, pp. 156-171.

Midtgard, T., Vadlamannati, K. and de Soysa, I. (2017), "Liberalization via IMF structural adjustment", Review of Int'l Organization, Vol. 9 No. 1, pp. 1-28.

Miklian, J. (2017a), "The dark side of new business", Harvard International Review, Vol. 38 No. 4, pp. 18-22

Miklian, J. (2017b), "Mapping business-peace interactions: opportunities and recommendations", Business, Peace and Sustainable Development, Vol. 2017 No. 10, pp. 3-27.

Miklian, J. (2019), "Contextualising and theorising economic development, local business and ethnic cleansing in Myanmar", Conflict, Security and Development, Vol. 9 No. 1, pp. 1-24.

Miklian, J. (2020), "The role of business in sustainable development and peacebuilding: observing interaction effects", Business and Politics, Vol. 21 No. 4, pp. 569-601.

Miklian, J. and Katsos, J. (2021), "Thriving in uncertain times", Harvard Business Review, forthcoming. 
Miklian, J. and Medina-Bickel, J.P. (2020), "Theorizing business and local peacebuilding through the 'footprints of peace' coffee project in rural Colombia", Business \& Society, Vol. 59 No. 4, pp. 676-715.

Miklian, J. and Rettberg, A. (2019), "From war-torn to peace-torn? Mapping business strategies in transition from conflict to peace in Colombia", in Miklian, J., Katsos, J. and Alluri, R. (Eds), Business, Peace and Sustinable Development, Routledge, London.

Miklian, J. and Schouten, P. (2019), "Broadening 'business', widening 'peace': a new research agenda on business and peacebuilding", Conflict, Security and Development, Vol. 19 No. 1, pp. 1-13.

Miklian, J., Schouten, P., Horst, C. and Rolandsen, Ø. (2018), "Business and Peacebuilding: Seven Ways to Maximize Positive Impact”, Peace Research Institute Oslo, Oslo, Norway.

Miklian, J., Katsos, J. and Alluri, R. (Eds) (2019), Business, Peace and Sustinable Development, Routledge, London.

Mills, R. and Fan, Q. (2006), "The investment climate in post-conflict situations", Policy Research Working Paper 4055. World Bank, Washington, DC.

Min, A. and Kudo, T. (2014), "Business conglomerates in the context of Myanmar's economic reform", in Lim, H. and Yamada, Y. (Eds), Myanmar's Integration with Global Economy: Outlook and Opportunities, Bangkok Research Center, Bangkok, pp. 138-173.

Min, A. and Kudo, T. (2016), "Business conglomerates in the context of Myanmar's economic reform", in Lim, H. and Yamada, Y. (Eds), Myanmar's Integration with the Global Economy: Outlook and Opportunities, Bangkok Research Center, Bangkok.

Mitra, A. and Gaur, S.S. (2020), "Does environmental concern drive Asian firms' governance?", Journal of Asia Business Studies, Vol. 14 No. 4, pp. 481-503.

Nielsen, T. and Riddle, L. (2009), "Investing in peace: the motivational dynamics of diaspora investment in post-conflict economies", Journal of Business Ethics, Vol. 89 No. S4, pp. 435-448.

Oetzel, J. and Getz, K. (2012), "Why and how might firms respond strategically to violent conflict?", Journal of International Business Studies, Vol. 43 No. 2, pp. 166-186.

Oetzel, J. and Miklian, J. (2017), "Multinational enterprises, risk management, and the business and economics of peace", Multinational Business Review, Vol. 25 No. 4, pp. 270-286.

Oetzel, J., Westermann-Behaylo, M., Koerber, C., Fort, T.L. and Rivera, J. (2009), "Business and peace: sketching the terrain", Journal of Business Ethics, Vol. 89 No. S4, pp. 351-373.

Pirson, M. and Lawrence, P. (2010), "Humanism in business-towards a paradigm shift?", Journal of Business Ethics, Vol. 93 No. 4, pp. 553-565.

Pisani, N., Kourula, A., Kolk, A. and Meijer, R. (2017), "How global is international CSR research? Insights and recommendations from a systematic review", Journal of World Business, Vol. 52 No. 5, pp. 591-614.

Porter, M.E. and Kramer, M.R. (2019), "Creating shared value", Harvard Business Review, Vol. 84 No. 12, pp. 62-77.

Press-Barnathan, G. (2006), "The neglected dimension of commercial liberalism: economic cooperation and transition to peace", Journal of Peace Research, Vol. 43 No. 3, pp. 261-278.

Rao, I. (2019), "Competing values in Asian business: evidence from India and Dubai", Journal of Asia Business Studies, Vol. 13 No. 1, pp. 97-107.

Rehbein, K., Waddock, S. and Graves, S.B. (2004), "Understanding shareholder activism: which corporations are targeted?", Business \& Society, Vol. 43 No. 3, pp. 239-267.

Rettberg, A. and Miklian, J. (2019), "Business strategies in transition from conflict to peace", in Miklian, J., Katsos, J. and Alluri, R, (Eds), Business and Peace: Beyond the UN Sustainable Development Goals, Routledge, London.

RIWI (2020), "How RDIT works", available at: https://riwi.com/how-rdit-works/ (accessed 30 September 2020).

Rogers, B. (2012), Burma: A Nation at the Crossroads, Random House, London.

Seeman, N. (2015), "Use data to challenge mental-health stigma”, Nature, Vol. 528 No. 7582, p. 309.

Sorens, J. and Ruger, W. (2015), "Globalisation and intrastate conflict: an empirical analysis", Civil Wars, Vol. 14 No. 4, pp. 381-401. 
Talbott, K., Waugh, J. and Batson, D. (2012), "Sharing the wealth: Burma's post-military rule and natural resource governance", Small Wars Journal, Vol. 26 No. 3.

Tan, P. and Lam, S.S. (2017), "Philanthropic foundations in Asia: highlights from Singapore, Myanmar, and China", Agence Francaise de Development Research Paper Series \#2017-58.

Taylor, R.H. (2013), "Myanmar's 'pivot' toward the shibboleth of 'democracy", Asian Affairs, Vol. 44 No. 3 , pp. 392-400.

Trompenaars, F. (1996), "Resolving international conflict: culture and business strategy", Business Strategy Review, Vol. 7 No. 3, pp. 51-68.

UNHRC (2018), "Report of the Independent International Fact-Finding Mission on Myanmar", A/HRC/39/ 64, UNHRC, Geneva, Switzerland.

United Nations (2017), "Darker and more dangerous: High Commissioner updates the Human Rights Council on human rights issues in 40 countries", Human Rights Council 36th session, Progress Report, 11 September, United Nations, New York, NY.

Vatillum, V. (2019), "RIWI Corp. Research Report”, Veritas Reports, February 19.

Westermann-Behaylo, M. (2009), "Institutionalizing peace through commerce: engagement or divestment in South African and Sudan", Journal of Business Ethics, Vol. 89 No. S4, pp. 417-434.

Winn, M., Kirchgeorg, M., Griffiths, A., Linnenluecke, M.K. and Günther, E. (2011), "Impacts from climate change on organizations: a conceptual foundation", Business Strategy and the Environment, Vol. 20 No. 3, pp. 157-173.

Woods, K. (2011), "Ceasefire capitalism: military-private partnerships, resource concessions and military-state building in the Burma-China borderlands", Journal of Peasant Studies, Vol. 38 No. 4, pp. 747-770.

Woods, K. (2017), "The war to rule: ceasefire capitalism and state-making in Burma's borderlands", UC Berkeley. ProQuest ID: Woods_berkeley_0028E_17468.

World Bank (2017), Fragility, Conflict and Violence Overview, World Bank, Washington, DC.

World Bank (2020), "New world bank partnership framework for Myanmar puts strong focus on social inclusion and peace", World Bank, Washington, DC, available at: www.worldbank.org/en/news/pressrelease/2020/05/18/new-world-bank-group-partnership-framework-for-myanmar-puts-strong-focus-onsocial-inclusion-and-peace (accessed 1 October 2020).

\section{Further reading}

McCarthy, G. (2018), Military Capitalism in Myanmar: Examining the Origins, Continuities and Evolution of "Khaki Capital", ISEAS: Cambridge University Press.

McCarthy, G. (2019), "Class dismissed? Explaining the absence of economic justice in the NLD's governing agenda", Journal of Current Southeast Asian Affairs, Vol. 38 No. 3, pp. 358-380. 


\section{Appendix}

Table A1 RIWI survey questionnaire

Q1

Q2aa

Q2a

Q2b

Q3

Q4
What is your nationality?

Myanmar national

Chinese

Indian

Southeast Asian

European/North American

Other

What is your employment status?

Work for a private firm with domestic ownership

Work for a foreign/international firm

Work for a non-governmental organization

Self-employed

Government

Military

Not employed/student

Other

Where is your company's main headquarters?

Myanmar and my company have major partnerships with foreign firms

Myanmar and my company have no major partnerships with foreign firms

China

India

Europe/North America

SE Asia

Other

What is your level of employment?

Entry level

Mid-level

Management

Director/Owner

In what sector does your firm work?

Retail/services

Manufacturing

Agriculture

Extractives (oil, gas, mining)

Banking

Technology/telecommunications

Does your business undertake any of the following corporate social responsibility (CSR) activities? (select all that apply) Philanthropy

Environmental protection

Human rights advocacy

Local community work

Pressure government for social improvement

Other CSR activities

No CSR activities

Does your business work with any of the UN sustainable development goals (SDGs)?

(If so, which does your business most prioritize?)

Goal 1 - Poverty

Goal 4 - Education

Goal 5 - Gender equality

Goal 8 - Economic growth

Goal 9 - Industry, innovation and infrastructure

Goal 12 - Responsible consumption and production

Goal 13 -Climate 
Table A1

Goal 16 - Peace, justice and strong institutions

No, we do not work with the SDGs

Don't know

Q5

Have new regulations since 2012 helped reduce corruption in Myanmar?

Much more corruption

A little more corruption

Neither worse nor better/no effect

A little less corruption

Much less corruption

Q6

Do you think the business community contributes to peace in Myanmar?

No and it shouldn't

No but should do more

Yes but should do less

Yes and should do more

Not relevant to business

Q7

Is foreign investment good or bad for social development in Myanmar?

Makes social development much worse

Makes social development a little worse

Makes no difference

Slightly improves social development

Greatly improves social development

Q8

Has the conflict in Rakhine state increased or decreased investment in Myanmar?

Significantly decreased

Slightly decreased

Neither increased nor decreased

Slightly increased

Significantly increased

Q9

Does foreign investment help encourage democracy in Myanmar?

No, it makes democracy much harder to achieve

No, it makes democracy a little harder to achieve

Has no impact

Yes, it makes democracy a little easier to achieve

Yes, it makes democracy a lot easier to achieve

Q10

How much is the business community doing to encourage democracy in Myanmar?

Very little and should do less

Very little but should do more

A lot but should do less

A lot and should do more

Not relevant to business

Q11 Does your firm do business in Rakhine state?

Yes

No

Q11a Does your firm do development and/or CSR work in Rakhine? (select all that apply)

(Multiselect) Philanthropy

Environmental protection

Human rights advocacy

Local community work

Pressure government for social improvement

Other CSR activities

No CSR activities

Q11b How are profits in Rakhine since 2012 compared to other parts of the country?

Much less profitable

(continued)

PAGE 616 JOURNAL OF ASIA BUSINESS STUDIES $\mid$ VOL. 16 NO. 42022 
Table A1

Slightly less profitable

No difference

Slightly more profitable

Much more profitable

Have since left the area in question

Q12 Does your firm do business in Shan, Karen or Kachin state? (select all that apply)

Shan state

Kachin state

Karen state

None of these

Q12a Does your firm do development/CSR work in these areas?

Yes

No

Q12b Should international development agencies help non-Burmese in these areas?

Yes

No

Q12C How profitable is your firm in these areas compared to other parts of the country?

Much less profitable

Slightly less profitable

No difference

Slightly more profitable

Much more profitable

Don't know

Q13 If a business helps ethnic minorities with jobs or development, does it impact profits?

Reduces profits substantially

Reduces profits slightly

No impact at all

Increases profits slightly

Increases profits substantially

\section{Corresponding author}

Jason Miklian can be contacted at: jason.miklian@sum.uio.no

For instructions on how to order reprints of this article, please visit our website:

www.emeraldgrouppublishing.com/licensing/reprints.htm

Or contact us for further details: permissions@emeraldinsight.com 